\title{
The -374 T/A polymorphism in the gene encoding RAGE is associated with diabetic nephropathy and retinopathy in type 1 diabetic patients
}

\author{
E. Lindholm • E. Bakhtadze • M. Sjögren • C. M. Cilio • \\ E. Agardh • L. Groop • C.-D. Agardh
}

Received: 13 December 2005 / Accepted: 21 June 2006 / Published online: 13 September 2006

(C) Springer-Verlag 2006

\begin{abstract}
Aims/hypothesis The receptor for AGE (RAGE) is considered to be mainly an intracellular signal-transducer or pro-inflammatory peptide of possible importance for inflammation and autoimmune diseases. Our aim was to study whether the $-374 \mathrm{~T} / \mathrm{A}$ polymorphism in the gene encoding RAGE $(A G E R)$ is associated with diabetes type and presence of diabetic complications.

Methods The AGER -374 T/A polymorphism was genotyped in 867 type 1 diabetic patients, 2,467 type 2 diabetic patients and 205 non-diabetic control subjects of Scandinavian origin.

Results AGER polymorphism was related to different $H L A$ $D Q B 1$ genotypes and the presence of diabetic complications. Type 1 diabetic patients had a higher frequency of the AGER $-374 \mathrm{~A} / \mathrm{A}$ or T/A genotypes than type 2 diabetic patients (51.1 vs $44.9 \%, p=0.002)$ and control subjects (51.1 vs $47.6 \%, p=0.0006$ ). The RAGE -374 T/A polymorphism was associated with $H L A-D Q B 1$ genotypes; patients with HLA risk genotypes had a higher frequency
\end{abstract}

Electronic supplementary material Supplementary material is available in the online version of this article at http://dx.doi.org/ $10.1007 / \mathrm{s} 00125-006-0412-3$ and is accessible to authorised users.

E. Lindholm • E. Bakhtadze · M. Sjögren · C. M. Cilio •

E. Agardh · L. Groop · C.-D. Agardh

Department of Clinical Sciences, University Hospital MAS,

Lund University,

Lund, Sweden

C.-D. Agardh $(\bowtie)$

Department of Endocrinology, University Hospital MAS,

SE-205 02 Malmo, Sweden

e-mail: carl-david.agardh@med.lu.se of the A/A or T/A genotypes than patients with other $H L A$ $D Q B 1$ genotypes (60.3 vs $40.3 \%, p<0.000001)$. In type 1 diabetic patients, the frequency of the $\mathrm{A} / \mathrm{A}$ or $\mathrm{T} / \mathrm{A}$ genotypes was higher in patients with diabetic nephropathy than without (61.1 vs $46.8 \%, p=0.006)$ and with sightthreatening retinopathy than without (56.1 vs $47.6 \%$, $p=0.03$ ). In type 2 diabetic patients with $\mathrm{HbA}_{1 \mathrm{c}}$ values below the median, the $\mathrm{T} / \mathrm{T}$ genotype was more frequent in patients with diabetic nephropathy than without (54.3 vs $38.2 \%, p=0.02$ ).

Conclusions/interpretation Our results show an association between the $A G E R-374$ T/A polymorphism and type 1 diabetes. This association was $H L A-D Q B 1$-dependent. The polymorphism was associated with diabetic nephropathy in both type 1 and type 2 diabetes, in an $\mathrm{HbA}_{1 \mathrm{c}}$-dependent manner in the latter group, and also with sight-threatening retinopathy in type 1 diabetic patients.

Keywords Diabetes - Diabetic complications - $H L A-D Q B 1$. Polymorphism · RAGE · Type 1 diabetes · Type 2 diabetes

\section{Introduction}

Poor glycaemic control, elevated blood pressure and smoking are well-established risk factors for the development of diabetic microvascular complications [1, 2]. 
However, the molecular pathophysiology is not yet fully understood. Three major pathways have been suggested to be involved in the pathogenesis of diabetic complications, i.e. glucose-induced activation of protein kinase $\mathrm{C}$ isoforms [3], increased flux through the aldose reductase pathway [4] and increased formation of glucose-derived AGEs [5]. Formation of AGEs is increased in diabetes due to chronic hyperglycaemia; blocking the formation of AGEs by aminoguanidine [6] or administration of soluble protein for RAGE (sRAGE) [7] prevents untoward effects of AGEs on the vascular wall in diabetic animals. AGEs are elevated in kidney failure, and in a recent study we have shown that the serum levels of hydroimidazolone are elevated in type 2 diabetic patients with retinopathy compared with those without [8].

Several receptors that mediate endocytosis and degradation of AGE-modified molecules have been identified [9]. One of these receptors is RAGE, which is a multiligand member of the immunoglobulin superfamily. It is less efficient in AGE endocytosis than the macrophage scavenger receptor [10], and might therefore mainly be considered as an intracellular signal and transducer or proinflammatory peptide [9]. The $\mathrm{S}$ allele of the gene encoding RAGE (AGER) G82S polymorphism has been shown to be more prevalent in patients with rheumatoid arthritis, suggesting that this gene also might be of importance in human autoimmune diseases [11]. In diabetic NOD mice the inhibition of the RAGE receptor seems to delay the onset of the disease [12].

There is a strong linkage disequilibrium between alleles at a number of loci in the major MHC on the short arm of chromosome 6, which also harbours the AGER 6p21.3.

Several polymorphisms in the $A G E R$ have been identified and associated with diabetic complications. Hudson et al. demonstrated that three polymorphisms $(-429 \mathrm{~T} / \mathrm{C}$, $-374 \mathrm{~T} / \mathrm{A}$ and a $63 \mathrm{bp}$ insertion/deletion polymorphism) increased transcriptional activity 2-4-fold. The $-374 \mathrm{~A}$ allele influenced binding to a transcription factor-binding site leading to upregulation of $A G E R$ transcription. All three polymorphisms were located at the $5^{\prime}$ flanking region of the $A G E R$; the $63 \mathrm{bp}$ insertion/deletion polymorphism overlapped with the $-374 \mathrm{~T} / \mathrm{A}$ polymorphism. The $-429 \mathrm{~T} / \mathrm{C}$ and $-374 \mathrm{~T} / \mathrm{A}$ polymorphism were prevalent, while $63 \mathrm{bp}$ I/D was rare (1-2\%) [13, 14].

Hudson et al. also showed an association between the $-429 \mathrm{~T} / \mathrm{C}$ polymorphism and retinopathy in type 2 diabetic patients [13]. However, other association studies have failed to demonstrate an association between these polymorphisms and diabetic retinopathy $[15,16]$ or nephropathy [17]. As is often the case in association studies of a polygenic disease, many of these studies have been underpowered. Interestingly, Pettersson-Fernholm et al. [18] found an association between the -374 T/A polymor- phism and diabetic nephropathy in Finnish type 1 diabetic patients with high $\mathrm{HbA}_{1 \mathrm{c}}$ [18]. They also showed a significant association between the AGER -374 T/A polymorphism and macrovascular disease; a similar association with cardiovascular disease had previously been demonstrated both in type 2 diabetic patients and in nondiabetic subjects [19-21]. Patients homozygous for the minor allele $(\mathrm{A} / \mathrm{A})$ had a reduced risk for cardiovascular disease.

Our aim was to perform a comprehensive association study in patients with both type 1 and type 2 diabetes, selected from a large local diabetes registry in Southern Sweden, to define whether the common AGER -374 T/A polymorphism was associated with the type of diabetes per se and/or with diabetic nephropathy, retinopathy, neuropathy and cardiovascular complications in particular. Given the fact that the gene encoding RAGE is located on the short arm of chromosome 6 close to the HLA locus, we also related the findings to the presence of $H L A-D Q B 1$ risk genotypes.

\section{Subjects and methods}

\section{Subjects}

Patients from a local diabetes registry in Southern Sweden [22], most of them enrolled at the Department of Endocrinology, University Hospital MAS, Malmo, formed the basis of the present study. A total of 4,205 patients and 205 Scandinavian, non-diabetic control subjects were genotyped for the -374 T/A AGER polymorphism. Patients were classified as having type $1(n=967)$ or type $2(n=3,238)$ diabetes by the attending physician using the World Health Organization (WHO) guidelines of 1985 [23] or, when diagnosed after 1 January 2001, according to the new WHO guidelines [24]. In general, classification of type 1 diabetes was based on the presence of severe hyperglycaemia and/or ketosis at diagnosis, low fasting C-peptide levels and presence of GAD antibodies (GADA). Of all patients classified as having type 1 diabetes, $91.0 \%$ had fasting C-peptide $<0.3 \mathrm{nmol} / 1$ and $54.9 \%$ were GADA-positive; in total $97.5 \%$ were either GADA-positive or had low C-peptide $(<0.3 \mathrm{nmol} / \mathrm{l})$. The majority of both type $1(90 \%)$ and type $2(76 \%)$ patients were of Scandinavian descent.

The Ethics committee of Malmo/Lund approved the study. Informed consent was obtained from all patients.

\section{Analytical techniques}

A detailed description of analytical and genotyping techniques can be found in the Electronic Supplementary Material. 
Assessment of complications

Diabetic nephropathy Diabetic nephropathy was defined as the presence of macroalbuminuria. Macroalbuminuria was considered present when at least two values above the cutoff limit for macroalbuminuria were recorded. One positive measurement only was considered as macroalbuminuria if the patient thereafter was treated with ACE inhibitors or angiotensin II receptor blockers or if the patient had previously had persistent microalbuminuria. Patients with other kidney diseases or onset of microalbuminuria after 70 years of age were excluded from the analysis. Normoalbuminuria required that all urinary albumin measurements were in the normal range, otherwise the albuminuria status was considered unknown. Duration of albuminuria was calculated from the onset of microalbuminuria when known, or from the latest measurement with no albuminuria. If not known $(60 \%$ of all the cases with micro- or macroalbuminuria, $39 \%$ in type 1 diabetic patients), the duration was calculated from the first registered value with micro- or macroalbuminuria. When calculating the genotype frequencies in patients with normoalbuminuria, only patients with diabetes duration $\geq 10$ years were included.

Diabetic retinopathy Information about the retinopathy status was available in 2,722 patients. Patients were divided into two groups: subjects with no or non-proliferative retinopathy and subjects with sight-threatening retinopathy, which included patients with proliferative retinopathy and/ or photocoagulation treatment (focal/grid or panretinal). The duration of sight-threatening retinopathy was defined from the first information of diagnosis or laser treatment. When calculating the genotype frequencies in patients without sight-threatening retinopathy only those with a diabetes duration $\geq 10$ years were included.

Diabetic neuropathy Peripheral sensory neuropathy was assessed by measuring vibration sensation thresholds by a biothesiometer on the medial malleoli (Bio-Thesiometer; Bio-Medical Instruments, Newbury, OH, USA) and defined as a threshold $\geq 25 \mathrm{~V}$. The vibration sensation threshold was known in 2,744 cases. The duration was calculated from the first value $\geq 25 \mathrm{~V}$, but in $82 \%$ of the cases, the true onset of neuropathy was not known. When calculating the genotype frequencies for patients with vibration threshold $<25 \mathrm{~V}$, only patients with a diabetes duration $\geq 10$ years were included.

Macrovascular disease Macrovascular disease was defined as previous myocardial infarction and/or stroke. The duration in relation to the onset of diabetes was calculated from the first episode of one of these conditions or, when not known, from the date this was updated in the patient record.

\section{Statistical analysis}

Data are presented as mean \pm SD or as median (25th-75th percentile). Fisher's exact test was used to test for significance of differences. To test differences between group means, the Student's two-tailed $t$ test was used for normally distributed values and the Mann-Whitney $U$ test for non-normally distributed medians. In order to assess factors associated with diabetic nephropathy and retinopathy, respectively, a multiple logistic regression analysis with forward selection was performed. All data were analysed with a NCSS 2000 (NCSS statistical software, Kaysville, UT, USA). A $p$ value $<0.05$ was considered statistically significant. Power analysis was made using Genetic Power calculator. The genotype relative risk was estimated as 1.5 for both heterozygous T/A and homozygous A/A (dominative model) [25].

\section{Results}

The frequencies of $A G E R-374 \mathrm{~T} / \mathrm{A}$ genotypes were: $\mathrm{T} / \mathrm{T}$ $49.0 \%, \mathrm{~T} / \mathrm{A} 43.7 \%$ and $\mathrm{A} / \mathrm{A} 7.3 \%$ in Scandinavian type 1 diabetic patients $(n=867), 55.1 \%, 38.4 \%$ and $6.5 \%$ in Scandinavian type 2 diabetic patients $(n=2,453)$, respectively, and $62.4 \%, 32.7 \%$ and $4.9 \%$ in non-diabetic control subjects $(n=205)$, respectively (Table 1$)$. The $A G E R$ T/A or $\mathrm{A} / \mathrm{A}$ genotype was more frequent in type 1 diabetic patients compared with control subjects $(p=0.0006)$ and compared with type 2 diabetic patients $(p=0.002)$. Genotype frequencies also different between type 2 diabetic patients and control subjects $(p=0.048)$; this difference was, however, not significant when adjusting for multiple comparisons and the allele frequencies did not differ between type 2 diabetic patients and control subjects. After stratification for

Table 1 Frequency of $A G E R-374$ T/A polymorphism in diabetic patients and non-diabetic control subjects

\begin{tabular}{llll}
\hline & $\mathrm{T} / \mathrm{T}$ & $\mathrm{T} / \mathrm{A}$ & $\mathrm{A} / \mathrm{A}$ \\
\hline Control subjects & $128(62.4)$ & $67(32.7)$ & $10(4.9)$ \\
T1D & $425(49.0)$ & $379(43.7)$ & $63(7.3)$ \\
T2D & $1,353(55.1)$ & $941(38.4)$ & $159(6.5)$ \\
\hline
\end{tabular}

Values are $n(\%)$

$p=0.0006$, T1D vs control subjects. $p=0.048$, T2D vs control subjects. $p=0.002$, T1D vs T2D. $p$ values are for differences between T/T vs

$\mathrm{T} / \mathrm{A}$ and A/A genotype. $T 1 D$, type 1 diabetes; $T 2 D$, type 2 diabetes 
$H L A-D Q B 1$ risk genotype there was no difference in the $A G E R-374$ T/A polymorphism between type 1 diabetic patients, type 2 diabetic patients and control subjects (results not shown).

Type 2 diabetic patients of other origin had significantly different genotype frequencies than Scandinavian patients $(47.1 \%, 41.9 \%$ and $11.0 \%$, respectively; $n=785$, $p=0.00003, d f=2)$. There were only 100 patients with type 1 diabetic patients of non-Scandinavian origin and no differences in genotype frequencies were seen between the two ethnic groups. For further analysis, all calculations were performed separately for type 1 and type 2 diabetic subjects, and only subjects of Scandinavian origin were included. The frequency of $A G E R 63 \mathrm{bp}$ insertion/deletion polymorphism was $1.6 \%$ and in non-Scandinavian type 1 and $4.7 \%$ type 2 diabetic patients. Corresponding values for Scandinavian patients were $0.6 \%$ and $0 \%$.

Association between $A G E R-374$ T/A polymorphism and $H L A-D Q B 1$ genotypes

The $A G E R-374$ T/A polymorphism was associated with $H L A-D Q B 1$ genotypes in type 1 and type 2 diabetes (Table 2). The genotypes with the minor allele $\mathrm{A}(\mathrm{A} / \mathrm{A}$ or $\mathrm{A} / \mathrm{T})$ were more common in patients with high-risk $H L A$ $D Q B 1$ genotypes $D Q B 1 * 02 / 0302, D Q B 1 * 0302 / X$ and $D Q B 1 * 0302 / 0604$ compared with subjects with protective or neutral genotypes in both type 1 diabetic (60.2 vs $36.9 \%$, $p<0.000001)$ and type 2 diabetic (60.3 vs $41.5 \%$, $p<0.000001)$ patients. This was mainly due an association with the $H L A-D Q B 1 * 0302$ and $D Q B 1 * 02$ alleles. Patients with the $D Q B 1^{*} 0302$ allele had a higher frequency of $A G E R-374 \mathrm{~A} / \mathrm{A}$ or T/A genotypes than patients without the $D Q B 1^{*} 0302$ allele (61.3 vs $\left.35.4 \%, p<0.000001\right)$, while the opposite was true for patients with the $D Q B 1 * 02$ allele (35.8 vs $57.1 \%, p<0.000001)$. In a logistic regression analysis with age at onset of diabetes, diabetes duration, sex, T/T genotype and $D Q B 1^{*} 02$ allele as independent variables, the $D Q B 1^{*} 02$ allele, but not the $\mathrm{T} / \mathrm{T}$ genotype was independently associated with GADA positivity in type 1 diabetic patients (results not shown).

Association between $A G E R-374$ T/A polymorphism and diabetic nephropathy

Type 1 diabetic patients with macroalbuminuria had lower age at diabetes diagnosis, longer diabetes duration, higher $\mathrm{HbA}_{1 \mathrm{c}}$ and systolic and diastolic blood pressure levels and were more often smokers than patients with normal AER (Table 3). Type 2 diabetic patients with diabetic nephropathy were younger, had longer diabetes duration and were younger at diabetes diagnosis, had higher $\mathrm{BMI}, \mathrm{HbA}_{1 \mathrm{c}}$ and systolic blood pressure and were more often smokers than type 2 diabetic patients with normoalbuminuria.

Type 1 diabetic patients with diabetic nephropathy had a higher frequency of the $\mathrm{A} / \mathrm{A}$ or $\mathrm{T} / \mathrm{A}$ genotype $(61.1 \%)$ compared with those with normoalbuminuria and $\geq 10$ years of diabetes duration $(46.8 \% ; p=0.006)$ (Table 4). In a multiple logistic regression analysis with macroalbuminuria as dependent variable, the $\mathrm{A} / \mathrm{A}$ or $\mathrm{T} / \mathrm{A}$ genotype was independently associated with a higher risk of macroalbuminuria (odds ratio $[\mathrm{OR}]=1.93, p=0.008$ ) in type 1 diabetic subjects (Table 5). There was no difference in $A G E R$ genotype frequencies between type 2 diabetic patients with and without macroalbuminuria. In a multiple logistic regression analysis age, diabetes duration, systolic blood pressure, $\mathrm{HbA}_{1 \mathrm{c}}$ and male sex, but not $A G E R-374$ T/A polymorphism, were associated with diabetic nephropathy in type 2 diabetes. Because a previous study has suggested a possible interaction of the metabolic control and the effect of $A G E R-374$ T/A polymorphism on diabetic nephropathy [18], we also tested the genotype frequencies in patients with $\mathrm{HbA}_{1 \mathrm{c}}$ below and above the median. Type 2 diabetic patients with $\mathrm{HbA}_{1 \mathrm{c}}$ below the median and with diabetic nephropathy had a lower frequency of the A/A or T/A genotypes than those with low $\mathrm{HbA}_{1 \mathrm{c}}$ and normoalbuminuria (38.2 vs $54.3 \%, p=0.04$ ) (Table 6). The frequency of A allele was higher in type 1 diabetic patients with nephropathy than without (35 vs $27 \%, p=0.03$ ). No difference in allele frequencies was observed in type 2 diabetic patients with or without diabetic nephropathy (minor allele frequency $25 \%$ and $28 \%$, respectively).

Association between $A G E R-374$ T/A polymorphism and diabetic retinopathy

Data on the retinopathy status were available from 2,737 subjects (848 with type 1 and 1,874 with type 2 diabetes). $A G E R-374 \mathrm{~A} / \mathrm{A}$ or $\mathrm{T} / \mathrm{A}$ genotypes were more common in type 1 diabetic patients with than without sight-threatening retinopathy (56.1 vs $47.6 \%, p=0.04)$. The frequency of A allele was higher in patients with sight-threatening retinopathy than in those without (32 vs $27 \%, p=0.03$ ). However, no association with sight-threatening retinopathy and $A G E R$ polymorphism was seen in a multiple regression analysis (Table 7). Stratifying for glycaemic control did not change the picture (Table 6). In type 2 diabetic patients the $A G E R-374$ T/A polymorphism was not associated with sight-threatening retinopathy either in all patients or in patients stratified for glycaemic control (Tables 4 and 6). There was no difference in allele frequencies in type 2 diabetic patients with or without sight-threatening retinopathy (minor allele frequency $28 \%$ in both groups). 
Table 2 Frequency of $A G E R-374 \mathrm{~A} / \mathrm{A}$ or T/A genotypes according to $H L A-D Q B 1$ genotype in control, type 1 diabetic and type 2 diabetic subjects

\begin{tabular}{|c|c|c|c|c|c|c|}
\hline & $\begin{array}{l}\text { Frequency of } \\
A G E R-374 \mathrm{~A} / \mathrm{A} \\
\text { or T/A genotypes } \\
\text { in control } \\
\text { subjects }\end{array}$ & $\begin{array}{l}\text { Frequency of } \\
A G E R-374 \mathrm{~A} / \mathrm{A} \\
\text { or T/A genotypes } \\
\text { in T1D }\end{array}$ & $\begin{array}{l}\text { Frequency of } \\
A G E R-374 \mathrm{~A} / \mathrm{A} \\
\text { or T/A genotypes } \\
\mathrm{T} 2 \mathrm{D}\end{array}$ & $\begin{array}{l}\text { Frequency of } \\
H L A-D Q B 1 \\
\text { genotype in } \\
\text { control subjects }\end{array}$ & $\begin{array}{l}\text { Frequency of } \\
H L A-D Q B 1 \\
\text { genotype in T1D }\end{array}$ & $\begin{array}{l}\text { Frequency of } \\
H L A-D Q B 1 \\
\text { genotype in } \\
\text { T2D }\end{array}$ \\
\hline $02 / 0301$ & $7(53.8)$ & 7 (26.9) & $26(39.4)$ & $13(6.4)$ & $27(3.3)$ & $66(5.6)$ \\
\hline $02 / 0302$ & $3(30.0)$ & $154(54.4)$ & $49(53.8)$ & $10(4.9)$ & $287(34.8)$ & $91(7.7)$ \\
\hline $02 / 0602^{\mathrm{a}}$ & $1(11.1)$ & $2(28.6)$ & $6(9.5)$ & $9(4.4)$ & $7(0.8)$ & $63(5.3)$ \\
\hline $02 / 0603^{\mathrm{a}}$ & $0(0.0)$ & $1(12.5)$ & $11(33.3)$ & $4(2.0)$ & $8(1.0)$ & $33(2.8)$ \\
\hline $02 / 0604$ & $1(14.3)$ & $2(8.0)$ & $2(8.3)$ & $7(3.4)$ & $25(3.0)$ & $24(2.0)$ \\
\hline $02 / \mathrm{X}$ & $6(25.0)$ & $26(20.8)$ & $38(24.7)$ & $24(11.8)$ & $126(15.3)$ & $154(13.1)$ \\
\hline $0301 / 0302$ & $3(42.9)$ & $29(69.0)$ & $36(65.5)$ & $7(3.4)$ & $43(5.2)$ & $55(4.7)$ \\
\hline $0301 / 0602^{\mathrm{a}}$ & $4(57.1)$ & $1(25.0)$ & $22(45.8)$ & $7(3.4)$ & $4(0.5)$ & $48(4.1)$ \\
\hline $0301 / 0603^{\mathrm{a}}$ & $1(16.7)$ & $2(50.0)$ & $9(40.9)$ & $6(3.0)$ & $4(0.5)$ & $22(1.9)$ \\
\hline $0301 / 0604^{a}$ & $3(75.0)$ & $1(25.0)$ & $9(69.2)$ & $4(2.0)$ & $4(0.5)$ & $13(1.1)$ \\
\hline $0301 / \mathrm{X}$ & $10(58.8)$ & $9(60.0)$ & $78(61.4)$ & $17(8.4)$ & $15(1.8)$ & $127(10.8)$ \\
\hline $0302 / 0602^{\mathrm{a}}$ & $1(16.7)$ & $3(50.0)$ & 37 (58.7) & $6(3.0)$ & $6(0.7)$ & $63(5.3)$ \\
\hline $0302 / 0603$ & $3(100.0)$ & $16(72.7)$ & $19(67.9)$ & $3(1.5)$ & $22(2.7)$ & $29(2.5)$ \\
\hline $0302 / 0604$ & $1(16.7)$ & $25(55.6)$ & 13 (61.9) & $6(3.0)$ & $46(5.6)$ & $21(1.8)$ \\
\hline 0302/X & $13(65.0)$ & $112(72.3)$ & $73(65.2)$ & $20(9.9)$ & $158(19.2)$ & $112(9.5)$ \\
\hline $0602 / 03 / 04 / \mathrm{X}$ & $9(39.1)$ & $6(54.5)$ & $45(45.5)$ & $23(11.3)$ & $11(1.3)$ & $99(8.4)$ \\
\hline $0602 / \mathrm{X}^{\mathrm{a}}$ & $5(21.7)$ & $0(0.0)$ & $30(30.6)$ & $23(11.3)$ & $2(0.2)$ & $98(8.3)$ \\
\hline 0604/X & $1(16.7)$ & $8(47.1)$ & $10(32.3)$ & $6(3.0)$ & $18(2.2)$ & $31(2.6)$ \\
\hline $\mathrm{X} / \mathrm{X}$ & $4(50.0)$ & $8(72.7)$ & $18(60.0)$ & $8(3.9)$ & $12(1.5)$ & $30(2.5)$ \\
\hline Total & & & & $203(100.0)$ & $825(100.0)$ & $1179(100.0)$ \\
\hline
\end{tabular}

Values are $n(\%)$

$p<0.000001$, chi-square $=113.6, d f=12$ in T1D,$p<0.000001$, chi-square $=146.4, d f=18$ in T2D

${ }^{a}$ Expected value $<5$ in T1D. These genotypes were pooled in the statistical analysis

$T 1 D$, type 1 diabetes; T2D, type 2 diabetes; $X$, either a homozygous allele or any allele other than $02,0301,0302,0602$ or 0604

Association between $A G E R-374$ T/A polymorphism and diabetic neuropathy

Information about neuropathy based upon assessment of vibration threshold was available from 2,187 patients (770 with type 1 diabetes and 1,417 with type 2 diabetes). The genotype frequencies of the AGER -374 T/A polymorphism did not differ between patients with or without neuropathy (Table 4), either in all patients or in patients with $\mathrm{HbA}_{1 \mathrm{c}}$ above and below the median (Table 6). In a multiple logistic regression analysis age, diabetes duration, $\mathrm{HbA}_{1 \mathrm{c}}$, systolic blood pressure and male sex were associated with diabetic neuropathy in both type 1 and type 2 diabetes (results not shown). In addition, in type 2 diabetes, the $A G E R-374$ T/A polymorphism was also an independent predictor. The A/A or T/A genotypes were associated with lower risk for diabetic neuropathy $(\mathrm{OR}=0.77, p=0.04)$. There was no difference in allele frequencies in type 1 or in type 2 diabetic patients with or without diabetic neuropathy (frequency of minor allele in type 1 diabetes $28 \%$ in both groups, in type 2 diabetes $25 \%$ and $27 \%$, respectively).

Association between $A G E R$-374 T/A polymorphism and macrovascular complications

Information on previous myocardial infarction or stroke was available from 2,275 patients (753 with type 1 and 1,522 with type 2 diabetes). There was no difference in the genotype frequency between patients with and without macrovascular complications (Table 4). A multiple logistic regression analysis with age, diabetes duration, plasma cholesterol, HDL-cholesterol and triglycerides, sex, current smoking, systolic and diastolic blood pressure and $A G E R-374$ T/A genotype as independent variables did not show any independent effect of the AGER polymorphism on macrovascular complications (results not shown). There was no difference in allele frequencies in type 1 or in type 2 diabetic patients with or without macrovascular complications (frequency of minor 
Table 3 Clinical characteristics of patients with normoalbuminuria, and nephropathy

\begin{tabular}{|c|c|c|c|c|}
\hline & \multicolumn{2}{|l|}{$\mathrm{T} 1 \mathrm{D}$} & \multicolumn{2}{|l|}{$\mathrm{T} 2 \mathrm{D}$} \\
\hline & No albuminuria & Nephropathy & No albuminuria & Nephropathy \\
\hline$n(\mathrm{M} / \mathrm{F})$ & $449(235 / 214)$ & $126(80 / 46)$ & $988(509 / 479)$ & $204(149 / 55)$ \\
\hline Age (years) ${ }^{\mathrm{b}}$ & $44.3 \pm 15.0$ & $43.5 \pm 14.3$ & $63.7 \pm 10.8$ & $58.8 \pm 7.7$ \\
\hline Age at diagnosis (years) ${ }^{\mathrm{a}, \mathrm{b}}$ & $25.2 \pm 15.4$ & $19.5 \pm 14.6$ & $56.6 \pm 10.7$ & $50.3 \pm 8.2$ \\
\hline Diabetes duration (years) ${ }^{\mathrm{a}, \mathrm{b}}$ & $16.6(8.9-26.7)$ & $20.0(15.0-27.5)$ & $5.3(2.1-10.5)$ & $7.5(2.1-13.0)$ \\
\hline BMI $\left(\mathrm{kg} / \mathrm{m}^{2}\right)^{\mathrm{b}}$ & $23.8 \pm 3.1$ & $24.1 \pm 3.0$ & $29.1 \pm 5.5$ & $30.0 \pm 5.4$ \\
\hline $\mathrm{HbA}_{1 \mathrm{c}}(\%)^{\mathrm{a}, \mathrm{b}}$ & $7.1 \pm 1.2$ & $7.9 \pm 1.2$ & $6.5 \pm 1.2$ & $7.2 \pm 1.2$ \\
\hline Systolic blood pressure $(\mathrm{mmHg})^{\mathrm{a}, \mathrm{b}}$ & $128.3 \pm 16.8$ & $143.8 \pm 20.9$ & $142.9 \pm 19.2$ & $149.8 \pm 18.8$ \\
\hline Diastolic blood pressure $(\mathrm{mmHg})^{\mathrm{a}}$ & $74.0 \pm 9.0$ & $77.5 \pm 10.6$ & $80.7 \pm 10.7$ & $82.0 \pm 11.2$ \\
\hline Total urinary albumin $(\mu \mathrm{g} / \mathrm{min})^{\mathrm{a}, \mathrm{b}}$ & $4(2-7)$ & $438(128-1324)$ & $6(3-10)$ & $281(117-816)$ \\
\hline P-creatinine $(\mu \mathrm{mol} / 1)^{\mathrm{a}, \mathrm{b}}$ & $75(67-82)$ & $100(89-122)$ & $78(69-89)$ & $91(79-110)$ \\
\hline Current smoking ${ }^{\mathrm{a}, \mathrm{b}}$ & $91(21.3)$ & $50(40.0)$ & $180(24.7)$ & $60(34.3)$ \\
\hline
\end{tabular}

Values are given as mean $\pm \mathrm{SD}$, median (25th-75th percentile) or $n(\%)$. Information was missing in $12 \%$ and $37 \%$ of the cases (T1D and T2D, respectively)

$p<0.05$, no albuminuria vs macroalbuminuria in ${ }^{\mathrm{a}} \mathrm{T} 1 \mathrm{D}$ and ${ }^{\mathrm{b}} \mathrm{T} 1 \mathrm{D}$ patients, respectively

$T 1 D$, type 1 diabetes; $T 2 D$, type 2 diabetes

allele in type 1 diabetes $31 \%$ and $29 \%$, in type 2 diabetes $23 \%$ and $27 \%$, respectively, $p=0.05$ ).

$H L A-D Q B 1$ genotype and diabetic complications

There was no difference in the frequency of diabetic complications between type 1 and type 2 diabetic subjects between carriers of different $H L A-D Q B 1$ genotypes or carriers of $H L A-D Q B 1$ risk genotypes vs non-risk genotypes (results not shown). Table 8 shows the frequency of $A G E R-374 \mathrm{~T} / \mathrm{A}$ polymorphism in relation to diabetic complications when stratified for $H L A-D Q B 1$ risk geno- types. In type 1 diabetic patients with $H L A-D Q B 1$ risk genotype the frequency of T/A or A/A genotype was higher in patients with diabetic nephropathy than in those without nephropathy (69.9 vs $49.7 \%, p=0.004)$ and also in patients with sight-threatening retinopathy than in patients without (65.7 vs $55.2 \%, p=0.04$ ). Adding the $H L A-D Q B 1$ risk genotype into the logistic regression analysis showed that the $A G E R$ T/A or A/A genotype was still an independent risk factor for diabetic nephropathy in type 1 diabetic patients $(\mathrm{OR}=1.93, p=0.01)$, even when the $H L A-D Q B 1$ risk genotype was included in the analysis. However, the $H L A-D Q B 1$ risk genotype $(\mathrm{OR}=1.59, p=0.01)$, but not the

Table $4 A G E R-374 \mathrm{~A} / \mathrm{T}$ genotype frequencies in relation to presence of diabetic complications in patients with type 1 and type 2 diabetes

\begin{tabular}{|c|c|c|c|c|c|c|}
\hline & \multicolumn{3}{|l|}{ T1D } & \multicolumn{3}{|l|}{$\mathrm{T} 2 \mathrm{D}$} \\
\hline & $\mathrm{T} / \mathrm{T}$ & $\mathrm{T} / \mathrm{A}$ & $\mathrm{A} / \mathrm{A}$ & $\mathrm{T} / \mathrm{T}$ & $\mathrm{T} / \mathrm{A}$ & $\mathrm{A} / \mathrm{A}$ \\
\hline \multicolumn{7}{|l|}{ Nephropathy } \\
\hline No & $169(53.1)$ & $127(39.9)$ & $22(6.9)$ & $138(51.7)$ & $106(39.7)$ & $23(8.6)$ \\
\hline Yes & $49(38.9)^{\mathrm{a}}$ & $67(53.2)$ & $10(7.9)$ & $115(56.4)$ & $78(38.2)$ & $11(5.4)$ \\
\hline \multicolumn{7}{|l|}{ Retinopathy } \\
\hline No/background & $200(52.4)^{\mathrm{b}}$ & $160(41.8)$ & $22(5.8)$ & $319(53.3)$ & $229(38.2)$ & $51(8.5)$ \\
\hline Sight-threatening & $137(43.9)$ & $150(48.1)$ & $25(8.0)$ & $142(51.1)$ & $119(42.8)$ & $17(6.1)$ \\
\hline \multicolumn{7}{|l|}{ Neuropathy } \\
\hline Vibration threshold $<25 \mathrm{~V}$ & $115(49.6)$ & $102(44.0)$ & $15(6.5)$ & $52(53.6)$ & $37(38.1)$ & $8(8.2)$ \\
\hline Vibration threshold $\geq 25 \mathrm{~V}$ & $207(49.1)$ & $191(45.3)$ & $24(5.7)$ & $533(55.6)$ & $362(37.8)$ & $63(6.6)$ \\
\hline \multicolumn{7}{|l|}{ Macrovascular complications } \\
\hline No & $324(49.8)$ & $280(43.0)$ & $47(7.2)$ & $581(54.2)$ & $414(38.6)$ & $77(7.2)$ \\
\hline Yes & $48(48.0)$ & $42(42.0)$ & $10(10.0)$ & $254(58.1)$ & $164(37.5)$ & $19(4.3)$ \\
\hline
\end{tabular}

Values are $n(\%)$

${ }^{\mathrm{a}} p=0.006$ for $\mathrm{T} / \mathrm{T}$ genotype vs $\mathrm{T} / \mathrm{A}+\mathrm{A} / \mathrm{A}$ genotype in T1D

${ }^{\mathrm{b}} p=0.03$ for $\mathrm{T} / \mathrm{T}$ genotype vs $\mathrm{T} / \mathrm{A}+\mathrm{A} / \mathrm{A}$ genotype in T1D. Duration $\geq 10$ years for patients without nephropathy, sight-threatening retinopathy and neuropathy, respectively

$T 1 D$, type 1 diabetes; $T 2 D$, type 2 diabetes 
Table 5 Multiple forward stepwise logistic regression analysis of nephropathy vs no albuminuria

\begin{tabular}{|c|c|c|c|c|c|c|}
\hline & \multicolumn{3}{|c|}{ Type 1 diabetes } & \multicolumn{3}{|c|}{ Type 2 diabetes } \\
\hline & Coefficient & Odds ratio & $p$ value & Coefficient & Odds ratio & $p$ value \\
\hline Age & -0.05 & - & 0.00002 & -0.07 & - & $<0.00001$ \\
\hline Diabetes duration & 0.03 & - & 0.002 & 0.05 & - & 0.001 \\
\hline $\mathrm{HbA}_{1 \mathrm{c}}$ & 0.53 & - & $<0.00001$ & 0.29 & - & 0.0002 \\
\hline Systolic blood pressure & 0.05 & - & $<0.00001$ & 0.04 & - & $<0.00001$ \\
\hline Diastolic blood pressure & 0.0009 & - & NS & -0.02 & - & NS \\
\hline BMI & 0.03 & - & NS & 0.03 & - & NS \\
\hline Smoking & 0.82 & $2.26(1.34-3.81)$ & 0.002 & 0.32 & $1.39(0.92-2.08)$ & NS \\
\hline Male sex & 0.59 & $1.81(1.09-3.00)$ & 0.02 & 1.01 & $2.76(1.82-4.20)$ & $<0.00001$ \\
\hline $\mathrm{A} / \mathrm{A}$ or $\mathrm{T} / \mathrm{A}$ genotype & 0.66 & $1.93(1.18-3.15)$ & 0.008 & -0.09 & $0.91(0.63-1.32)$ & NS \\
\hline
\end{tabular}

AGER -374 T/A polymorphism, was an independent risk factor for sight-threatening retinopathy in type 1 diabetic patients.

In type 2 diabetic patients with the $H L A-D Q B 1$ risk genotype, the T/A and A/A genotype was more common in patients with sight-threatening retinopathy than in those without ( 82.1 vs $54.1 \%, p=0.01$ ). When $H L A-D Q B 1$ risk genotype was included in the logistic regression model, neither the $A G E R$ polymorphism nor the $H L A-D Q B 1$ risk genotype was an independent risk factor for sight-threatening retinopathy in type 2 diabetic patients (results not shown).

The $A G E R-374$ T/A polymorphism was not associated with diabetic neuropathy even when stratified for $H L A$ $D Q B 1$ risk genotypes (Table 8).

No significant difference in $A G E R-374$ T/A polymorphism was observed between type 1 diabetic patients with or without macrovascular disease after stratification for $H L A-D Q B 1$ risk genotypes. However, the $H L A-D Q B 1$ risk genotype itself was associated with macrovascular disease in type 1 diabetic patients, because the protective genotypes were significantly associated with increased frequency of macrovascular disease $(\mathrm{OR}=1.82, p=0.02)$. Indeed, the $A G E R \mathrm{~T} / \mathrm{A}$ or $\mathrm{A} / \mathrm{A}$ genotype was less common in type 2 diabetic patients (having $H L A-D Q B 1$ risk genotype) with than without macrovascular disease (44.1 vs $66.4 \%$, $p=0.03$ ). Neither the $A G E R$ polymorphism nor the HLA$D Q B 1$ risk genotype was a significant risk factor for macrovascular disease in type 2 diabetes when the $H L A$ $D Q B 1$ risk genotype was added to the model (results not shown).

\section{Discussion}

A novel finding of the present study was the strong association between $A G E R-374 \mathrm{~T} / \mathrm{A}$ polymorphism and $H L A-D Q B 1$ genotype (Table 2). This is not surprising, as

Table 6 Frequency of $A G E R-374 \mathrm{~A} / \mathrm{A}$ or T/A genotypes in diabetic complications stratified according to type of diabetes and $\mathrm{HbA}_{1 \mathrm{c}}$ levels

\begin{tabular}{|c|c|c|c|c|}
\hline & \multicolumn{2}{|c|}{ Type 1 diabetes } & \multicolumn{2}{|c|}{ Type 2 diabetes } \\
\hline & Without & With & Without & With \\
\hline \multicolumn{5}{|l|}{ Nephropathy } \\
\hline Low $\mathrm{HbA}_{1 \mathrm{c}}$ & $82(45.1 \%)^{\mathrm{a}}$ & $29(65.9 \%)$ & $57(54.3 \%)^{\mathrm{b}}$ & $30(38.2 \%)$ \\
\hline High $\mathrm{HbA}_{1 \mathrm{c}}$ & $65(48.5 \%)$ & $48(58.5 \%)$ & $72(44.4 \%)$ & $58(46.4 \%)$ \\
\hline \multicolumn{5}{|l|}{ Retinopathy } \\
\hline Low $\mathrm{HbA}_{1 \mathrm{c}}$ & $108(47.6 \%)$ & $57(53.3 \%)$ & $132(51.6 \%)$ & $26(39.4 \%)$ \\
\hline High $\mathrm{HbA}_{1 \mathrm{c}}$ & $71(47.7 \%)$ & $118(57.6 \%)$ & $152(43.7 \%)$ & $112(52.3 \%)$ \\
\hline \multicolumn{5}{|l|}{ Neuropathy } \\
\hline Low $\mathrm{HbA}_{1 \mathrm{c}}$ & $64(47.8 \%)$ & $89(50.0 \%)$ & $20(54.1 \%)$ & $171(46.3 \%)$ \\
\hline High $\mathrm{HbA}_{1 \mathrm{c}}$ & $52(53.1 \%)$ & $126(51.9 \%)$ & $28(44.4 \%)$ & $259(43.4 \%)$ \\
\hline \multicolumn{5}{|c|}{ Macrovascular complications } \\
\hline Low $\mathrm{HbA}_{1 \mathrm{c}}$ & $156(46.6 \%)$ & $20(46.6 \%)$ & $255(49.4 \%)$ & $73(41.0 \%)$ \\
\hline High $\mathrm{HbA}_{1 \mathrm{c}}$ & $170(54.0 \%)$ & $32(55.2 \%)$ & $235(42.4 \%)$ & $109(42.2 \%)$ \\
\hline
\end{tabular}

Values are $n(\%)$

${ }^{\mathrm{a}} p=0.02,{ }^{\mathrm{b}} p=0.04$

Duration $\geq 10$ years for patients without nephropathy, retinopathy or neuropathy, respectively 
Table 7 Multiple forward stepwise logistic regression analysis with sight-threatening retinopathy as the independent variable

\begin{tabular}{|c|c|c|c|c|c|c|}
\hline & \multicolumn{3}{|c|}{ Type 1 diabetes } & \multicolumn{3}{|c|}{ Type 2 diabetes } \\
\hline & Coefficient & Odds ratio & $p$ value & Coefficient & Odds ratio & $p$ value \\
\hline Age & -0.04 & - & $<0.00001$ & -0.01 & - & 0.046 \\
\hline Diabetes duration & 0.07 & - & $<0.00001$ & 0.09 & - & $<0.00001$ \\
\hline $\mathrm{HbA}_{1 \mathrm{c}}$ & 0.63 & - & $<0.00001$ & 0.32 & - & $<0.00001$ \\
\hline Systolic BP & 0.03 & - & $<0.00001$ & 0.01 & - & 0.001 \\
\hline Diastolic BP & 0.01 & - & NS & 0.008 & - & NS \\
\hline Smoking & -0.15 & $0.86(0.57-1.30)$ & NS & -0.31 & $0.76(0.52-1.12)$ & NS \\
\hline Male sex & 0.44 & $1.55(1.10-2.17)$ & 0.01 & 0.15 & $1.15(0.85-1.57)$ & NS \\
\hline $\mathrm{A} / \mathrm{A}$ or $\mathrm{T} / \mathrm{A}$ genotype & 0.2 & $1.27(0.91-1.78)$ & NS & 0.16 & $1.16(0.86-1.55)$ & NS \\
\hline
\end{tabular}

the $A G E R$ receptor is located on the chromosome 6 in the $\mathrm{MHC}$ region. This region is very gene-dense and contains a number of inflammatory genes [26]. A special feature of the $\mathrm{MHC}$ is the strong linkage disequilibrium between alleles at a number of loci $[27,28]$.

The frequency of $A G E R$ polymorphism varied according to type of diabetes and ethnic background. The AGER -374 $\mathrm{T} / \mathrm{A}$ or $\mathrm{A} / \mathrm{A}$ genotypes were more frequent in type 1 diabetic patients than in non-diabetic control subjects and in type 2 diabetic patients. There was also a borderline significance between type 2 diabetic patients and control subjects; however, the difference was small and may be due to type I error. A larger control group would be needed to definitely be able to solve this issue. The differences in $A G E R$ polymorphism frequency between type 1 and type 2 diabetic patients seemed to be a consequence of the differences in HLA haplotypes, because the stratification for $H L A-D Q B 1$ risk genotype abolished these differences. The AGER -374 polymorphism was not independently associated with GADA positivity, whereas the $D Q B 1^{*} 02$ allele showed a strong association with GADA positivity [29].

We also showed that the minor allele $\mathrm{A}(\mathrm{A} / \mathrm{A}$ or $\mathrm{T} / \mathrm{A}$ genotype) is a risk factor for diabetic nephropathy and sight-threatening retinopathy in type 1 diabetic, but not in type 2 diabetic subjects. The association between $A G E R$ -374 T/A polymorphism and diabetic nephropathy and sight-threatening retinopathy was independent of $H L A$ $D Q B 1$ genotypes. The association with diabetic nephropathy was also independent of metabolic control, blood pressure and other known risk factors (Table 5). Intriguingly, in type 2 diabetic patients with low $\mathrm{HbA}_{1 \mathrm{c}}$, the A allele seems to protect against diabetic nephropathy. A similar trend, although not statistically significant, was seen for diabetic retinopathy, neuropathy and macrovascular complications, the A/A or T/A genotypes being less frequent with than without retinopathy, neuropathy and macrovascular complications in type 2 diabetic patients

Table 8 Frequency of $A G E R-374$ genotypes in diabetic complications stratified according to type of diabetes and $H L A-D Q B 1$ risk genotype $(D Q B 1 * 02 / 0302, D Q B 1 * 0302 / X$ and $D Q B 1 * 0302 / 0604)$

\begin{tabular}{|c|c|c|c|c|}
\hline & \multicolumn{2}{|l|}{ Type 1 diabetes } & \multicolumn{2}{|l|}{ Type 2 diabetes } \\
\hline & High risk & Low risk or protective & High risk & Low risk or protective \\
\hline \multicolumn{5}{|l|}{ Nephropathy } \\
\hline No & $92 / 79 / 12(50.3 / 43.2 / 6.6)$ & $73 / 36 / 9(61.9 / 30.5 / 7.6)$ & $16 / 19 / 2(43.2 / 51.4 / 5.4)$ & 75/47/15 (54.7/34.3/10.9) \\
\hline Yes & $22 / 43 / 8(30.1 / 58.9 / 11.0)^{\mathrm{a}}$ & $26 / 22 / 2(52.0 / 44.0 / 4.0)$ & $15 / 15 / 2(46.9 / 46.9 / 6.3)$ & $58 / 45 / 6(53.2 / 41.3 / 5.5)$ \\
\hline \multicolumn{5}{|l|}{ Retinopathy } \\
\hline None/background & $100 / 111 / 12(44.8 / 49.8 / 5.4)$ & $84 / 36 / 10(64.6 / 27.7 / 7.7)$ & $33 / 32 / 8(45.2 / 43.8 / 11.0)$ & $141 / 88 / 21(56.4 / 35.2 / 8.4)$ \\
\hline Sight-threatening & $60 / 97 / 18(34.3 / 55.4 / 10.3)^{\mathrm{b}}$ & $69 / 46 / 6(57.0 / 38.0 / 5.0)$ & $5 / 18 / 5(17.9 / 64.3 / 17.9)^{\mathrm{c}}$ & $73 / 55 / 5(54.9 / 41.4 / 3.8)$ \\
\hline \multicolumn{5}{|l|}{ Neuropathy } \\
\hline Vibration threshold $<25 \mathrm{~V}$ & $62 / 70 / 8(44.3 / 50.0 / 5.7)$ & $51 / 20 / 7(65.4 / 25.6 / 9.0)$ & $3 / 4 / 3(30.0 / 40.0 / 30.0)$ & $24 / 11 / 2(64.9 / 29.7 / 5.4)$ \\
\hline Vibration threshold $\geq 25 \mathrm{~V}$ & $92 / 135 / 15(38.0 / 55.8 / 6.2)$ & $102 / 53 / 8(62.6 / 32.5 / 4.9)$ & $44 / 54 / 11(40.4 / 49.5 / 10.1)$ & $254 / 146 / 25(59.8 / 34.4 / 5.9)$ \\
\hline \multicolumn{5}{|c|}{ Macrovascular complications } \\
\hline No & $147 / 189 / 30(40.2 / 51.6 / 8.2)$ & $152 / 66 / 17(64.7 / 28.1 / 7.2)$ & $41 / 64 / 17(33.6 / 52.5 / 13.9)$ & $241 / 148 / 25(58.2 / 35.7 / 6.0)$ \\
\hline Yes & $18 / 24 / 4(39.1 / 52.2 / 8.7)$ & $23 / 16 / 5(52.3 / 36.4 / 11.4)$ & $19 / 14 / 1(55.9 / 41.2 / 2.9)^{\mathrm{d}}$ & $106 / 54 / 8(63.1 / 32.1 / 4.8)$ \\
\hline
\end{tabular}

${ }^{\mathrm{a}} p=0.004, \mathrm{~T} / \mathrm{T}$ genotype vs $\mathrm{T} / \mathrm{A}+\mathrm{A} / \mathrm{A}$ genotype (with diabetic nephropathy vs without)

${ }^{\mathrm{b}} p=0.04, \mathrm{~T} / \mathrm{T}$ genotype vs $\mathrm{T} / \mathrm{A}+\mathrm{A} / \mathrm{A}$ genotype (with sight-threatening retinopathy vs without)

${ }^{c} p=0.01, \mathrm{~T} / \mathrm{T}$ genotype vs $\mathrm{T} / \mathrm{A}+\mathrm{A} / \mathrm{A}$ genotype (with sight-threatening retinopathy vs without)

${ }^{\mathrm{d}} p=0.03, \mathrm{~T} / \mathrm{T}$ genotype vs $\mathrm{T} / \mathrm{A}+\mathrm{A} / \mathrm{A}$ genotype (with macrovascular complications vs without) 
with good metabolic control. One explanation could be that the $A G E R$ polymorphism itself would influence glycaemic control. However, the $\mathrm{HbA}_{1 \mathrm{c}}$ did not differ between the different genotype carriers in type 1 diabetes (T/T 7.38\%, T/A 7.48\%, A/A 7.58\%) or in type 2 diabetes (T/T $6.88 \%$, T/A $6.78 \%$, A/A 6.99\%).

Clearly our study had enough power to detect differences in the allele frequencies in nephropathy in type 1 diabetic patients. Assuming genotypic relative risk of 1.5, the power was $>94 \%$ to detect differences in diabetic retinopathy, neuropathy and macrovascular disease in both type 1 and type 2 diabetic patients, and also to detect possible differences in nephropathy in type 2 diabetic patients $(\alpha=0.05)$. Therefore, it seems clear that the $A G E R$ $-374 \mathrm{~T} / \mathrm{A}$ polymorphism is mainly a risk factor for diabetic nephropathy in type 1 diabetic patients and seems to have a minor impact, if any, in other complications and in type 2 diabetic patients. The $p$ value of 0.006 observed in type 1 diabetic patients with and without diabetic nephropathy is still significant even if corrected for multiple comparisons (four).

It has been assumed that the underlying pathophysiological mechanism leading to late diabetic complications are similar in type 1 and type 2 diabetes, but different modifying factors may be operative in the two forms of diabetes, including genetic factors. One such genetic factor could be polymorphism in the gene encoding RAGE. In fact, in the current study the $A G E R$ polymorphism showed almost opposite effects on late diabetic complications in type 1 and type 2 diabetes. Whereas the increased risk conferred by the $A G E R$ polymorphism was straightforward in type 1 diabetes (microangiopathy), the effect was much more complex in type 2 diabetes, suggesting that other factors, such as insulin resistance [30, 31], hypertension, obesity, dyslipidaemia and ischaemic renal disease, but also other genetic factors, might be of greater importance in the development of diabetic complications in type 2 than in type 1 diabetes.

Our observation that the A allele was a risk factor for diabetic nephropathy conflicts with a recent study in Finnish type 1 diabetic patients, in whom the A/A genotype was protective in patients with high $\mathrm{HbA}_{1 \mathrm{c}}$ [18]. Similarly, studies on macrovascular disease in type 2 diabetic and in non-diabetic patients [19-21] have shown a protective role of the A allele. However, several other studies support the role of A allele as a risk factor rather than a protective factor against diabetic complications. The A allele has shown to have a threefold increased transcriptional activity and it has been shown that overexpression of $A G E R$ in a double transgenic diabetic mouse led to enhanced albuminuria, mesangial expansion and glomerulosclerosis [32]. Similarly, treatment with sRAGE can decrease the risk of nephropathy in the $d b / d b$ mouse [33]. It would therefore be plausible to expect that the A allele is more frequent in patients with than without complications. Our observation that the A allele is a risk factor for diabetic nephropathy and retinopathy is therefore in accordance with these previous observations [13, 32, 33].

There are several possible explanations for the differences observed in this study and the FinnDiane study [18], such as differences in study design and ethnic background. The frequency of $A G E R-374 \mathrm{~T} / \mathrm{A}$ polymorphism was strongly dependent on the $H L A-D Q B 1$ genotype, the frequency of which can vary in different populations [34], and therefore also the frequency of $A G E R-374 \mathrm{~T} / \mathrm{A}$ polymorphism. The frequency of the $63 \mathrm{bp}$ insertion/ deletion polymorphism was also lower in Scandinavian patients than in patients of other origins. Because the deletion allele has a fourfold increased transcriptional activity, a higher prevalence in certain populations could confer increased susceptibility to diabetic complications in these populations. Finally, because of its location in the $\mathrm{MHC}$ region and the strong linkage disequilibrium between different HLA loci, it is possible that at least some of the associations found with the $A G E R$ and diabetic complications may in fact be due to variations in other genes in the same region. A few but not all previous studies have shown an association between diabetic nephropathy or retinopathy and HLA genotype [35-38]. We could not find any direct association between $H L A-D Q B 1$ risk genotype and diabetic complications. However, the association between $A G E R$ -374 T/A polymorphism and diabetic nephropathy and retinopathy in type 1 diabetic patients was only significant in patients with $H L A-D Q B 1$ risk genotype (Table 8). Intriguingly, macrovascular disease was associated with $A G E R-374 \mathrm{~T} / \mathrm{A}$ polymorphism in type 2 diabetic patients with $H L A-D Q B 1$ risk genotype, the $\mathrm{T} / \mathrm{T}$ genotype being more frequent in patients with macrovascular disease than in those without. Given the small number of type 2 diabetic patients having the $H L A-D Q B 1$ risk genotype and the fact that the figures are not corrected for multiple comparisons, we cannot exclude a type I error. The MHC region is very gene-dense and many of the genes are involved in inflammation and therefore also possible candidate genes for diabetic complications. Recently, the TNF- $\alpha 308 \mathrm{G} / \mathrm{A}$ polymorphism has been shown to be associated with diabetic nephropathy in obese Chinese type 2 diabetic patients [39]. Another possible confounder is the LTA T60N polymorphism that has previously been associated with insulin resistance and type 2 diabetes [40].

Taken together, our results suggest that $A G E R-374 \mathrm{~T} / \mathrm{A}$ polymorphism is associated with diabetic complications, most strongly with diabetic nephropathy. The fact that the $H L A-D Q B 1$ genotype is associated with this polymorphism explains the observed differences in the genotype frequency of $A G E R$ polymorphism between type 1 and type 2 
diabetes. The association of the $A G E R-374$ T/A polymorphism and late diabetic complications seems to be much more complex than previously thought, and could explain why previous studies have failed to show any association between diabetic complications and AGER -374 T/A polymorphism. There seems to be a difference in how this polymorphism affects the risk of diabetic complications depending both on the type of diabetes and on degree of metabolic control. Finally, we cannot exclude the possibility that other gene variations in the same region play a role in the development of diabetic complications.

Acknowledgements This study was supported by Skane County Council Research and Development Foundation and the Medical Research Council of Lundberg.

\section{References}

1. The Diabetes Control and Complications Trial Research Group (1993) The effect of intensive treatment of diabetes on the development and progression of long-term complications in insulin-dependent diabetes mellitus. N Engl J Med 329:977-986

2. UK Prospective Diabetes Study (UKPDS) Group (1998) Intensive blood-glucose control with sulphonylureas or insulin compared with conventional treatment and risk of complications in patients with type 2 diabetes (UKPDS 33). Lancet 352:837-853

3. Koya D, King GL (1998) Protein kinase C activation and the development of diabetic complications. Diabetes 47:859-866

4. Lee AY, Chung SK, Chung SS (1995) Demonstration that polyol accumulation is responsible for diabetic cataract by the use of transgenic mice expressing the aldose reductase gene in the lens. Proc Natl Acad Sci USA 92:2780-2784

5. Brownlee M (1995) Advanced protein glycosylation in diabetes and aging. Annu Rev Med 46:223-234

6. Brownlee M, Vlassara H, Kooney A, Ulrich P, Cerami A (1986) Aminoguanidine prevents diabetes-induced arterial wall protein cross-linking. Science 232:1629-1632

7. Bucciarelli LG, Wendt T, Qu W et al (2002) RAGE blockade stabilizes established atherosclerosis in diabetic apolipoprotein Enull mice. Circulation 106:2827-2835

8. Fosmark D, Torjesen P, Kilhovd B et al (2006) Increased serum levels of the specific advanced glycation end product methylglyoxal-derived hydroimidazolone are associated with retinopathy in patients with type 2 diabetes. Metabolism 55:232-236

9. Vlassara H, Palace MR (2003) Glycoxidation: the menace of diabetes and aging. Mt Sinai J Med 70:232-241

10. Mackic JB, Stins M, McComb JG et al (1998) Human bloodbrain barrier receptors for Alzheimer's amyloid-beta 1-40. Asymmetrical binding, endocytosis, and transcytosis at the apical side of brain microvascular endothelial cell monolayer. J Clin Invest 102:734-743

11. Hofmann MA, Drury S, Hudson BI et al (2002) RAGE and arthritis: the G82S polymorphism amplifies the inflammatory response. Genes Immun 3:123-135

12. Chen Y, Yan SS, Colgan J et al (2004) Blockade of late stages of autoimmune diabetes by inhibition of the receptor for advanced glycation end products. J Immunol 173:1399-1405

13. Hudson BI, Stickland MH, Futers TS, Grant PJ (2001) Effects of novel polymorphisms in the RAGE gene on transcriptional regulation and their association with diabetic retinopathy. Diabetes 50:1505-1511

14. Rudofsky G Jr, Isermann B, Schilling T et al (2004) A 63 bp deletion in the promoter of RAGE correlates with a decreased risk for nephropathy in patients with type 2 diabetes. Exp Clin Endocrinol Diabetes 112:135-141

15. Globocnik Petrovic M, Steblovnik K, Peterlin B, Petrovic D (2003) The $-429 \mathrm{~T} / \mathrm{C}$ and $-374 \mathrm{~T} / \mathrm{A}$ gene polymorphisms of the receptor of advanced glycation end products gene are not risk factors for diabetic retinopathy in Caucasians with type 2 diabetes. Klin Monatsbl Augenheilkd 220:873-876

16. JiXiong X, BiLin X, MingGong Y, ShuQin L (2003) -429T/C and $-374 \mathrm{~T} / \mathrm{A}$ polymorphisms of RAGE gene promoter are not associated with diabetic retinopathy in Chinese patients with type 2 diabetes. Diabetes Care 26:2696-2697

17. Poirier O, Nicaud V, Vionnet N et al (2001) Polymorphism screening of four genes encoding advanced glycation end-product putative receptors. Association study with nephropathy in type 1 diabetic patients. Diabetes 50:1214-1218

18. Pettersson-Fernholm K, Forsblom C, Hudson BI, Perola M, Grant P, Groop PH (2003) The functional -374 T/A RAGE gene polymorphism is associated with proteinuria and cardiovascular disease in type 1 diabetic patients. Diabetes 52:891-894

19. dos Santos KG, Canani LH, Gross JL, Tschiedel B, Pires Souto KE, Roisenberg I (2005) The $-374 \mathrm{~A}$ allele of the receptor for advanced glycation end products gene is associated with a decreased risk of ischemic heart disease in African-Brazilians with type 2 diabetes. Mol Genet Metab 85:149-156

20. Falcone C, Campo I, Emanuele E et al (2005) -374T/A polymorphism of the RAGE gene promoter in relation to severity of coronary atherosclerosis. Clin Chim Acta 354:111-116

21. Falcone C, Campo I, Emanuele E et al (2004) Relationship between the $-374 \mathrm{~T} / \mathrm{A}$ RAGE gene polymorphism and angiographic coronary artery disease. Int J Mol Med 14:1061-1064

22. Lindholm E, Agardh E, Tuomi T, Groop L, Agardh CD (2001) Classifying diabetes according to the new WHO clinical stages. Eur J Epidemiol 17:983-989

23. World Health Organization Study Group (1985) Diabetes mellitus. In: World Health Organization Technical Report Series 727. WHO, Geneva

24. Alberti KG, Zimmet PZ (1998) Definition, diagnosis and classification of diabetes mellitus and its complications. Part 1: Diagnosis and classification of diabetes mellitus provisional report of a WHO consultation. Diabet Med 15:539-553

25. Purcell S, Cherny SS, Sham PC (2003) Genetic Power Calculator: design of linkage and association genetic mapping studies of complex traits. Bioinformatics 19:149-150

26. Rhodes DA, Trowsdale J (1999) Genetics and molecular genetics of the MHC. Rev Immunogenet 1:21-31

27. Degli-Esposti MA, Leaver AL, Christiansen FT, Witt CS, Abraham LJ, Dawkins RL (1992) Ancestral haplotypes: conserved population MHC haplotypes. Hum Immunol $34: 242-252$

28. Zhang WJ, Degli-Esposti MA, Cobain TJ, Cameron PU, Christiansen FT, Dawkins RL (1990) Differences in gene copy number carried by different MHC ancestral haplotypes. Quantitation after physical separation of haplotypes by pulsed field gel electrophoresis. J Exp Med 171:2101-2114

29. Hagopian WA, Sanjeevi CB, Kockum I et al (1995) Glutamate decarboxylase-, insulin-, and islet cell-antibodies and HLA typing to detect diabetes in a general population-based study of Swedish children. J Clin Invest 95:1505-1511

30. Forsblom CM, Eriksson JG, Ekstrand AV, Teppo AM, Taskinen MR, Groop LC (1995) Insulin resistance and abnormal albumin excretion in non-diabetic first-degree relatives of patients with NIDDM. Diabetologia 38:363-369 
31. Groop L, Ekstrand A, Forsblom C et al (1993) Insulin resistance, hypertension and microalbuminuria in patients with type 2 (non-insulin-dependent) diabetes mellitus. Diabetologia 36: 642-647

32. Yamamoto Y, Kato I, Doi $T$ et al (2001) Development and prevention of advanced diabetic nephropathy in RAGE-overexpressing mice. J Clin Invest 108:261-268

33. Wendt TM, Tanji N, Guo J et al (2003) RAGE drives the development of glomerulosclerosis and implicates podocyte activation in the pathogenesis of diabetic nephropathy. Am J Pathol 162:1123-1137

34. Hermann R, Bartsocas CS, Soltesz G et al (2004) Genetic screening for individuals at high risk for T1D in the general population using HLA Class II alleles as disease markers. A comparison between three European populations with variable rates of disease incidence. Diabetes Metab Res Rev 20:322-329

35. Chowdhury TA, Dyer PH, Mijovic CH, Dunger DB, Barnett AH, Bain SC (1999) Human leucocyte antigen and insulin gene regions and nephropathy in type I diabetes. Diabetologia 42:1017-1020
36. Wong TY, Cruickshank KJ, Klein R et al (2002) HLA-DR3 and DR4 and their relation to the incidence and progression of diabetic retinopathy. Ophthalmology 109:275-281

37. Agardh E, Gaur LK, Lernmark A, Agardh CD (2004) HLADRB1, -DQA1, and -DQB1 subtypes or ACE gene polymorphisms do not seem to be risk markers for severe retinopathy in younger type 1 diabetic patients. J Diabetes Complicat 18:32-36

38. Quiroz-Mercado H, Suarez-Licona A, Fromow-Guerra J et al (2002) Human lymphocyte antigen DR7 protects against proliferative retinopathy with type II diabetes mellitus. Arch Med Res 33:12312-12317

39. Wang Y, Ng MC, So WY et al (2005) Association between tumour necrosis factor- $\alpha \mathrm{G}-308 \mathrm{~A}$ polymorphism and risk of nephropathy in obese Chinese type 2 diabetic patients. Nephrol Dial Transplant 20:2733-2838

40. Hamid YH, Urhammer SA, Glumer C et al (2005) The common T60N polymorphism of the lymphotoxin-alpha gene is associated with type 2 diabetes and other phenotypes of the metabolic syndrome. Diabetologia 48:445-451 